\title{
Paradoxical Relationship between Free Will and Karma
}

Gauri $\mathbf{P}^{*}$

Department of Philosophy, Delhi University, New Delhi, India

*Corresponding author: Gauri P, Department of Philosophy, Delhi University, New Delhi, India, Tel: +91-8860812374; E-mail: gauripande1996@gmail.com

Received date: June 05, 2018; Accepted date: June 15, 2018; Published date: June 21, 2018

Copyright: (c) 2018 Gauri P. This is an open-access article distributed under the terms of the Creative Commons Attribution License, which permits unrestricted use, distribution, and reproduction in any medium, provided the original author and source are credited.

Citation: Gauri P (2018) Paradoxical Relationship between Free Will and Karma. Arts Social Sci J 9: 377. doi:10.4172/2151-6200.1000377

\section{Commentary}

After years of extensive researches on the concept of God and Evil, the only thing philosophers could affirm in favor of theists was that God created a world of Free Will, where good and evil exist on the discretion of the inhabitants of the world. Everyone is free to do as they will without any restrictions from the Ultimate reality. God created the world and left it to be operated by humans. But if God granted Free Will then who would ensure justice in the Universe? We know the limits of an evil mind and the worst limit of the human mind is that it has no limit. Who will protect good from evil? This is where the laws of Karma chime in. If we dig a grave for someone; we shall be prepared to end up in a grave someone else digs for us. This is how karmic paybacks work. Karma is the law of constant paybacks fall apart at several occasions but the creator of the world never rests when it comes to punishments in his court of Justice invented by the ultimate reality. The human justice system may arriving at the science of Karmic cosmos, we might find Newton's 3rd law of motion worth giving a look at. "Every action has an equal and opposite reaction." Although, Newton's law purely dealt with physics but those who know his philosophical side might surely agree that it has some cosmic relevance. After all, isn't this exactly how karma pays back? If you take away a man's sight, be prepared to feel the same in your life. It isn't necessary that you might go blind too but you certainly will feel the pain that man felt because of your actions. This may be the only way in which karma differs from Newtonian law, it doesn't really believe in the concept of opposite reaction. Karma works on the rule of pain. Karma does not only repay the harms a person may have caused to others; it also repays the good deeds performed by a man in his life.

Mostly all philosophical school have acknowledged the karmic law and they believe that whatever goes around, always comes around. Immanuel Kant is one of the most distinguished philosophers western philosophy could ever come across. His book, Ground works of the Metaphysics of Morals, can be summed up into one short sentence'Do unto others what you want done to you'. The brilliance of his work could not be put into question by any philosopher. Of course, there are several philosophers who have questioned how the philosophy might work but those who read his philosophy thoroughly will surely know that his philosophy is inspired by the karmic law of justice. Every philosopher has received his share of criticism from his fellow philosophers but that has never implied that just because your philosophy receives criticism it means that it's not life altering. Talking about the Indian aspects of the Karmic Law, Bhagavad Gita, consists of a section on Nishkam Karma Yoga' which states that all the actions performed shall be selfless and produced out of nothing but good will. It means that we should always choose the right thing to do.
Unfortunately, history is an evidence that no theory can be fully applicable to human beings. There are always some loopholes which destroy the practical application of every theory. In Mahabharata, Karna stood by Duryodhana even when he found out that his brothers were on the other side. In fact, in Ramayana, Raavan's (antagonist) brother Kumbhakaran went to his brother before the war with God Rama took place and told him that they were going to pay for their sins and inspite of that chose to take his brother's side because of his unconditional love for him. He was not able to leave his brother that because he did wrong. For him, it was better to die than to turn his back on the one he loves. What will he be considered then? Epitome of morality in one particular context or the proof of evil in another context? Well, he will just be called an ordinary human being because hardly anybody is able to make rational and just decision when who they love is at stake. Even Gautama Buddha, who was the creator of Buddhist Philosophy, believed that a man's life is the result of all the actions he performed in the past. The only way to end this continuous cycle of rebirth and pain is to perform good, selfless deeds.

This is exactly what history has taught us! Every battle will have a winner and a loser. Tears will be shed and lives will be destroyed. Some will fight for a good cause and some will fight for a bad cause. Those fighting for a good cause will do so because it's the right thing to do; all those fighting for a bad cause will stick to it because their courage is worth more than their lives. Anybody can have courage, even a stupid man! What takes real strength is to choose the path which can not only enrich your life but will also enrich the lives of various other people. We are all rational beings who do everything for a reason. Life is all about the paths we choose. Our Karma only teaches us that no good will ever arise from bad actions. The paths we choose today will determine our actions and then the consequences of our actions. God couldn't force the functioning of this universe so he made each person the creator of their own destinies with the hope that the fear of horrendous repercussions will enable a person to make good choices in life. Even if some choose to go the other way, their life will be a lesson about how our choices can determine our happiness/sorrows. God doesn't let evil prevail in this world; it is us humans whose actions have close resemblance to evil. If we fix our actions then the evil will be eradicated as well. The only thing God did was ensure that no deed went unpaid. He must have known that not all humans can be preachers of peace; there will be some who would want to disrupt that peace for the fun of it. The reasons however, can go unmentioned. This is why Karma can never take a rest. It will always give us what we gave to others and that is how ultimate justice has worked and will continue to work. 